\title{
ANALISIS HUBUNGAN EKSPOR, IMPOR, INFLASI DAN TINGKAT SUKU BUNGA TERHADAP KURS RUPIAH
}

\author{
1) Yulianti Rusdiana, ${ }^{2)}$ Nina Valentika, ${ }^{3)}$ Ilmadi, ${ }^{4)}$ Isnurani \\ ${ }^{1)}$ Universitas Pamulang, Kampus $2 \mathrm{Jl}$. Raya Puspitek No.46, Buaran, Serpong; \\ dosen00868@unpam.ac.id \\ 2) Universitas Pamulang, Kampus 2 Jl. Raya Puspitek No.46, Buaran, Serpong; \\ dosen02339@unpam.ac.id \\ 3) Universitas Pamulang, Kampus 2 Jl. Raya Puspitek No.46, Buaran, Serpong; \\ dosen01926@unpam.ac.id \\ 4) Universitas Pamulang, Kampus $2 \mathrm{Jl}$. Raya Puspitek No.46, Buaran, Serpong;
} dosen01193@unpam.ac.id

\begin{abstract}
Received :
01-10-2020

Accepted :

03-05-2021

Published :

05-05-2021
\end{abstract}

\begin{abstract}
This study modifies Silitonga RBR et.al (2017) research by adding an interest rate variable. This study aims to determine the relationship between exports, imports, inflation, and interest rates on the rupiah exchange rate in Indonesia. The analysis used in this research is multiple linear regression analysis. The data period starts from January 2009 to December 2019. Based on multiple linear regression analysis, it is found that no significant variables are affecting the rupiah exchange rate.
\end{abstract}

Keywords: regression, macroeconomic variables

\begin{abstract}
Abstrak
Penelitian ini memodifikasi Penelitian Silitonga RBR et.al (2017) dengan menambahkan variabel suku bunga. Penelitian ini bertujuan untuk mengetahui hubungan ekspor, impor, inflasi, dan suku bunga terhadap nilai tukar rupiah di Indonesia. Analisis yang digunakan dalam penelitian ini adalah analisis regresi linier berganda. Periode data mulai dari Januari 2009 sampai dengan Desember 2019. Berdasarkan analisis regresi linier berganda, diperoleh bahwa tidak ada variabel yang signifikan memengaruhi kurs rupiah.
\end{abstract}

Kata Kunci: regresi, variabel makro ekonomi

\section{Pendahuluan}

Investasi adalah komitmen terhadap sederet dana atau aset lain yang dilaksanakan saat ini untuk memperoleh sederet manfaat di masa yang akan datang. Saat ini, seorang investor membeli beberapa saham dengan harapan mendapat untung dari kenaikan harga saham atau sejumlah dividen di masa depan, sebagai hadiah atas waktu dan risiko yang terkait dengan investasi. Konsep investasi dapat mencakup berbagai aktivitas. Menginvestasikan sejumlah uang dalam aset riil (tanah, emas, mesin atau bangunan) atau aset keuangan (deposito, saham atau obligasi) adalah aktivitas investasi normal. Untuk investor yang lebih cerdas dan berisiko, aktivitas investasi mereka dapat mencakup investasi pada aset keuangan lain yang lebih kompleks, seperti waran, opsi, dan kontrak berjangka, serta saham internasional (Tandelilin 2010). 
Dalam membuat keputusan dari alokasi penginvestasian uang di beberapa Negara atau dalam negeri berbentuk bentuk saham, obligasi atau kas yang digunakan untuk menganalisis ekonomi dan pasar modal. Kecenderungan hubungan kuat antara hal yang terjadi pada lingkungan ekonomi makro dan kinerja suatu pasar modal adalah hal yang diperlukan dalam menganalisis ekonomi. Pertimbangkan analisis ekonomi makro dalam mengestimasi aliran kas, bunga maupun premi risiko dari suatu sekuritas (Tandelilin 2010). Operasi perusahaan sehari-hari yang dipengaruhi lingkungan disebut lingkungan ekonomi makro. Keputusan investasi yang menguntungkan dibuat untuk pemahaman dan peramalan kondisi ekonomi makro di masa datang yang sangat berguna sebagai kemampuan investor (Tandelilin 2010). Penyusunan anggaran pendapatan dan belanja Negara (APBN) yang merupakan salah satu indikator makroekonomi adalah nilai tukar rupiah terhadap US\$. Nilai tukar rupiah dikaitkan dengan indikator makro lain. Kurs dipengaruhi oleh faktor ekspor, impor dan inflasi (Sukirno 2010).

Inflasi adalah tren kenaikan harga produk secara keseluruhan. Laju inflasi yang tinggi seringkali dikaitkan dengan kondisi ekonomi yang sangat panas. Artinya, kondisi perekonomian sedang mengalami permintaan produk yang melebihi kapasitas pasokan produknya, sehingga harga cenderung naik. Inflasi yang terlalu tinggi juga akan menurunkan daya beli uang. Inflasi yang tinggi juga dapat menurunkan tingkat keuntungan riil yang diperoleh investor dari investasinya. Sebaliknya jika tingkat inflasi suatu negara turun maka akan menjadi sinyal positif bagi investor, karena daya beli uang akan berkurang dan risiko penurunan pendapatan riil akan berkurang (Tandelilín 2010). Impor adalah tindakan legal masuknya barang atau produk dari satu negara ke negara lain berdasarkan hukum perdagangan internasional. Kegiatan impor merupakan bagian penting dari perdagangan internasional untuk memenuhi kebutuhan masyarakat (Benny 2013).

Ekspor adalah kegiatan menjual barang / jasa dari daerah pabean sesuai dengan ketentuan peraturan perundang-undangan yang berlaku (Tambun et.al 2014). Menurut Sukirno (2010), nilai tukar dapat diartikan sebagai jumlah uang dalam negeri yang dibutuhkan, yaitu jumlah rupiah yang dibutuhkan untuk memperoleh satu unit mata uang asing. Suku bunga adalah harga penggunaan uang selama periode waktu tertentu, atau harga penggunaan uang yang saat ini digunakan dan akan dikembalikan di masa yang akan datang (Madura, 2006). 
Salah satu penelitian mengenai variabel makroekonomi adalah Penelitian Silitonga RBR et.al (2017). Penelitian Silitonga RBR et.al (2017) menganalisis ekspor, impor, dan inflasi terhadap nilai tukar rupiah di Indonesia. Metode yang digunakan dalam Penelitian Silitonga RBR et.al (2017) adalah regresi linear berganda. Penelitian Silitonga RBR et.al (2017) menemukan variabel ekspor dan impor (net ekspor) berpengaruh negatif dan signifikan terhadap variabel nilai tukar rupiah atas dolar Amerika Serikat sedangkan variabel inflasi tidak signifikan terhadap variabel nilai tukar rupiah atas dollar Amerika Serikat. Penelitian lain yang menggunakan analisis regresi linier berganda adalah Rahman (2019). Rahman (2019) meneliti minat belajar, kecerdasan logik matematik siswa, prestasi belajar. Penelitian ini menggunakan analisis regresi linier berganda. Penelitian ini memodifikasi Penelitian Silitonga RBR et.al (2017) dengan menambahkan variabel suku bunga. Sehingga, penelitian ini bertujuan untuk mengetahui hubungan ekspor, impor, inflasi, dan suku bunga terhadap nilai tukar rupiah di Indonesia dengan menggunakan regresi linear berganda.

\section{Metode Penelitian}

Periode data mulai dari Januari 2009 sampai dengan Desember 2019. Jumlah Nilai Ekspor, Impor, Tingkat Inflasi, Suku Bunga dan Kurs Rupiah adalah variabel yang digunakan dalam penelitian ini. Jenis dan sumber data pada penelitian ini adalah Data sekunder yaitu data yang bersumber dari publikasi laman resmi dari Bank Indonesia (BI) dan Badan Pusat Statistik (BPS). Pendekatan kajian dalam penelitian ini menggunakan pengujian secara statistik dengan menggunakan software EViews.

Model regresi linear berganda yang digunakan dalam penelitian ini untuk melihat hubungan Jumlah Nilai Ekspor, Impor, Tingkat Inflasi, dan Suku Bunga terhadap Kurs Rupiah. Adapun langkah yang dilakukan adalah:

1. Mengumpulkan data bulanan jumlah nilai ekspor, jumlah nilai impor, tingkat inflasi, tingkat suku bunga dan kurs rupiah mulai dari Januari 2009 sampai dengan Desember 2019.

2. Data bulanan jumlah nilai ekspor, jumlah nilai impor, dan kurs rupiah dijadikan dalam bentuk logaritma natural. Sedangkan tingkat inflasi dan tingkat suku bunga tidak dalam bentuk logaritma natural.

3. Mengestimasi parameter pada model Jumlah Nilai Ekspor, Impor, Tingkat Inflasi, Suku Bunga terhadap Kurs Rupiah dengan menggunakan analisis regresi linier berganda. 
4. Menguji diagnostik model, dilakukan untuk memastikan model yang didapat telah memenuhi asumsi dan layak digunakan.

\section{Hasil dan Pembahasan}

Model yang digunakan dalam penelitian ini dapat dilihat pada persamaan (1).

$$
Y_{t}=\alpha+\beta_{1} X_{1 t}+\beta_{2} X_{2 t}+\beta_{3} X_{3 t}+\beta_{4} X_{4 t}+\varepsilon_{t}
$$

dengan $Y$ adalah kurs rupiah, $X_{1}$ adalah inflasi, $X_{2}$ adalah ekspor, $X_{3}$ adalah impor, $X_{4}$ adalah suku bunga, $\alpha$ dan $\beta_{i}$ adalah parameter. $\varepsilon_{t}$ adalah error term pada waktu t. Model akhir yang memenuhi semua asumsi disajikan pada persamaan (2).

$$
Y_{t}=0.268511-0.003333 X_{1 t}+0.017230 X_{2 t}+0.002875 X_{3 t}-0.014175 X_{4 t}+\varepsilon_{t}
$$

dengan $t$ adalah waktu.

Tabel 1. Signifikansi model regresi

\begin{tabular}{cccc}
\hline Variabel & Koefisien & t-statistic & P-Value \\
\hline Konstanta & $0.268511^{*}$ & 27.19130 & 0.0000 \\
Inflasi & -0.003333 & -0.011575 & 0.9908 \\
Ekspor & 0.017230 & 0.924077 & 0.3572 \\
Impor & 0.002875 & 0.193426 & 0.8469 \\
Tingkat Suku Bunga & -0.014175 & -0.012934 & 0.9897 \\
\hline
\end{tabular}

*signifikan pada taraf nyata $5 \%$

Hasil Tabel 1 menunjukkan bahwa P-Value untuk variabel inflasi adalah sebesar 0.9908 yang lebih besar dari taraf nyata 5\%. Sehingga, variabel inflasi tidak berpengaruh signifikan terhadap kurs rupiah. P-value untuk variabel ekspor adalah sebesar 0.3572 yang lebih besar dari taraf nyata 5\%. Sehingga, variabel jumlah nilai ekspor tidak berpengaruh signifikan terhadap kurs rupiah. P-value untuk variabel impor adalah sebesar 0.8469 yang lebih besar dari taraf nyata $5 \%$. Sehingga, variabel jumlah nilai impor tidak berpengaruh signifikan terhadap kurs rupiah. P-value untuk variabel tingkat suku bunga adalah sebesar 0.9897 yang lebih besar dari taraf nyata 5\%. Sehingga, variabel tingkat suku bunga tidak berpengaruh signifikan terhadap kurs rupiah. Akibatnya, tidak ada variabel yang signifikan memengaruhi kurs rupiah. Pengujian asumsi autokorelasi untuk model regresi disajikan pada Tabel 2.

Tabel 2 Pengujian Autokorelasi

$\begin{array}{cc}\text { t-statistic } & \text { P-Value } \\ 2.107 & 0.7801\end{array}$


Hasil Tabel 2 menunjukkan bahwa t-statistic pada pengujian autokorelasi adalah sebesar 2.107. P-value pada pengujian autokorelasi adalah sebesar 0.7801. Karena Pvalue sebesar 0.7801 lebih besar dari taraf nyata 5\%, maka tidak ada autokorelasi atau korelasi serial antara sisaan dengan taraf nyata 5\%. Dengan kata lain, sisaan menyebar bebas dengan taraf nyata 5\%. Pengujian asumsi untuk heteroskedastisitas disajikan pada Tabel 3.

Tabel 3 Pengujian Heteroskedastisitas

$\begin{array}{lc}\text { t-statistic } & \text { P-Value } \\ 6.416 & 0.1702\end{array}$

Tabel 3 menunjukkan bahwa t-statistic pada pengujian heteroskedastisitas adalah sebesar 6.416. P-Value pada pengujian heteroskedastisitas adalah sebesar 0.1702. Karena P-value sebesar 0.1702 lebih besar dari taraf nyata 5\%, maka ragam sisaan homogen dengan taraf nyata 5\%. Pengujian asumsi untuk normalitas disajikan pada Tabel 4.

Tabel 4 Pengujian Normalitas dengan Kolmogorov-Smirnov

\begin{tabular}{cc}
\hline t-statistic & P-Value \\
0.07054 & 0.5372 \\
\hline
\end{tabular}

Hasil Tabel 4 diperoleh bahwa t-statistic pada pengujian normalitas adalah sebesar 0.07054. P-Value pada pengujian normalitas adalah sebesar 0.5372. Karena P-Value sebesar 0.5372 lebih besar daripada taraf nyata $5 \%$, maka sisaan menyebar normal pada taraf nyata 5\%. Pengujian asumsi untuk multikolinearitas disajikan pada Tabel 5.

Tabel 5 Pengujian asumsi multikolinearitas

\begin{tabular}{cc}
\hline Variabel & Nilai VIF \\
\hline Inflasi & 1.009 \\
Ekspor & 2.587 \\
Impor & 2.581 \\
Tingkat Suku Bunga & 1.169 \\
\hline
\end{tabular}

Berdasarkan Tabel 5 diperoleh bahwa variabel inflasi memiliki VIF sebesar 1.009. Jumlah Nilai Ekspor memiliki VIF sebesar 2.587. Jumlah Nilai Impor memiliki VIF sebesar 2.581. Tingkat Suku Bunga memiliki VIF sebesar 1.169. Sehingga, semua variabel memiliki nilai VIF lebih kecil daripada 10, sehingga tidak ada multikolinearitas.

Model regresi pada persamaan (2) memiliki R-Square adalah sebesar 2.3754\%. Hal ini menunjukkan bahwa sebesar $2.3754 \%$ keragaman kurs rupiah dapat dijelaskan oleh jumlah nilai ekspor, jumlah nilai impor, inflasi, dan tingkat suku bunga, sedangkan sisanya tidak dapat dijelaskan oleh model. 


\section{Kesimpulan dan Saran}

Simpulan dari penelitian ini adalah tidak ada variabel yang signifikan memengaruhi kurs rupiah dengan menggunakan model regresi linier berganda.

\section{Ucapan Terima Kasih}

Penelitian ini didanai oleh Kementerian Riset dan Teknologi/Badan Riset dan Inovasi Nasional, No. 0113/D5/KP/LPPM/IV/2020.

\section{Pustaka}

Benny M. (2013). Ekspor dan Impor Pengaruhnya terhadap Posisi Cadangan Devisa di Indonesia. Jurnal EMBA, 1(4), 1406-1415.

Madura, J. (2006). Keuangan Perusahaan Internasional. Edisi kedelapan. Jakarta: Salemba Empat.

Rahman A. N. (2019). Pengaruh Minat Belajar dan Kecerdasan Logik Matematik Siswa Terhadap Prestasi Belajar Matematika Siswa Kelas X SMK Se Jakarta Selatan. Jurnal Saintika Unpam, 1(2), 166-176.

Silitonga R. B. R, Ishak Z, and Mukhlis. (2017). Pengaruh Ekspor, impor, dan inflasi terhadap nilai tukar rupiah di Indonesia. Jurnal Ekonomi Pembangunan, 15(1), 5339.

Sukirno, Sadono. (2010). Makro Ekonomi Teori Pengantar. Edisi Ketiga. Jakarta (ID): Rajawali Pers.

Tambun N, Palar S, Rompas W. (2014). Analisis Struktur dan Kinerja Ekspor Komoditas Pertanian Pasca Krisis Ekonomi di Sulawesi Utara. Jurnal Berkala Ilmiah Efisien, 14(01), 01-12.

Tandelilin E. (2010). Portofolio dan Investasi Teori dan Aplikasi. Yogyakarta (ID): Kanisius. 